\title{
Anal Carcinoma: A Series of Cases with a Literature Review
}

\author{
Momčilo Stošić1, Igor Stojanović ${ }^{1}$, Svetlana Mihajlović1 ${ }^{1}$ Kosta Zdravković ${ }^{2}$ \\ ${ }^{1}$ Department of Surgery, Health Center Vranje, Vranje, Serbia \\ ${ }^{2}$ Daily Hospital for Hemotherapy, Health Center Vranje, Vranje, Serbia
}

\section{SUMMARY}

The aim of this study was to analyze the cases of five patients with squamous cell carcinoma (SCC) and to draw attention to the dilemma in the treatment of incontinence on admission of these patients and to present, through a literature review, locations of the surgical treatment.

The anal carcinoma is a rare disease which involves different histopathological (HP) types of cancer. They account for about $2.5 \%$ of all digestive cancers. The treatment of the disease is multimodal. There are dilemmas about screening of precancerous lesions and treatment of diagnosed incontinence. There is a high similarity between HPV infection and SCC. Our methods and results were compared with the data from the literature.

In the period of three years (from 2013 to 2015), five cases of the anal carcinoma were diagnosed and treated in the regional hospital. In all of our cases, the disease was histopathologically confirmed as SCC of the anal and perianal areas. It excluded the cases of anal adenocarcinoma (AAC).

Nearly half of the patients $(40 \%)$ were incontinent and the rectum excision was one of the possible solutions. Distinction in histopathological structure created the confusion in the treatment of these patients. The dilemma we had was whether to do an amputation of the rectum in patients with incontinence before the standardized Chemoradiation therapy (CRT). The review of the literature sums up certain conclu-sions.

The diagnosis of SCC includes the perianal "ulcer" that does not heal, as well as atypical anoperianal growths. Surgical treatment of SCC is indicated when the diameter of lesion is small $(2 \mathrm{~cm})$, or the disease is persistent or recurrent. In the case of anal incontinence because of the tumor changes, the abdominoperineal resection of the rectum (APR) is an alternative to performing bipolar colostomy and CRT. The review of the literature using MEDLINE/PubMed databases did not find the case with restoring anal continence after this treatment. Testing a larger number of patients with incontinence on admission would provide a more clear answer to the question of the treatment of these patients.

Key words:anal carcinoma, squamous cell carcinoma, chemoradiation therapy

Corresponding author:

Momčilo Stošić

Email: momcilostosic@gmail.com 


\section{INTRODUCTION}

The incidence of anal cancer is increasing. They are defined by the localization and they can be histopathologically very heterogeneous. The anal cancer makes up $1.5 \%$ (1) - $2.4 \%$ (2) of all cancers of the digestive system. The average age of the patients is 60 years. The anal carcinoma is divided into the anal canal carcinoma, perianal carcinoma (in the anal margin up to $5 \mathrm{~cm}$ from the entrance to the anus) and skin carcinoma (3). Histopathologically, $80 \%$ of the cancers of the anal canal are of the squamous type, $5-10 \%$ are adenocarcinoma, and the remaining $5 \%$ include neuroendocrine neoplasmas, mesenchymal tumors, lymphomas, melanocyte tumors and secondary tumors.

In the past decade, the etiology of the disease has changed, giving importance to connection between a viral infection in general and the development of SCC. There is an analogy between SCC and cervical cancer. The development of the disease is also attributed to the compromised immunological defense of the body (homosexuality, HIV, post-transplantation immunosuppression, etc).

The diagnosis is based on symptomatology (the growth of an ulcer which does not heal, itching, bleeding, etc), inspection, and biopsy. Endoanal ultrasound (EUS) is used to determinate the invasion into the anal sphincter as well as the post-therapeutic effect (4).

Computed tomography (CT) and magnetic resonance imaging (MRI) can occasionally be used for the evaluation of lymph nodes, as well as lymphnode biopsy (SLNB) or PET scan, (5) and palpation of the inguinal and abdominal lymph node. MSCT is a better solution compared with the abdominal or X-ray imaging.

Thirty years ago, the standard treatment was an abdominoperineal resection by Miles (APR) for intra- anal cancers and a wide excision for perianal SCCs. The work of Nigro from 1974 (6) was crucial for the treatment of the intra-anal cancers by means of the CRT, and it marked the change in the treatment strategy. This strategy proposes to eradicate a tumor without sacrificing the anal sphincter. The key question is what to do when there is incontinence, complete or partial, due to tumor ingrowth into the anal sphincter.

The paper highlights and analyzes SCC. The aim of the paper is to draw attention to the dilemma in the treatment of incontinence on admission of these patients, and to present, through a literature review, locations of the surgical treatment.

\section{CASE REPORTS}

\section{Case report No1}

A male, 63-years-old, was diagnosed with the anal squamous cell carcinoma, confirmed with biopsy. He had incontinence and was prescribed the CRT (54Gy+5FU/leucovorin in standard doses) which did not result in disease regression. Ca 19-9 and CEA were high. Therefore, a wide APR was done without complications. Six months later, a local recurrence was diagnosed and, soon after that a systematic development of the diseases as well. He was the only patient who died in follow-up of four years.

\section{Case report No 2}

A male, 68-years-old with diagnosed SCC (Figure 1a) had refused any treatment until he started bleeding from the anus. Then, an anal stenosis was also diagnosed by means of the rectal examination (Figure 1b). He had no metastasis. A classic X-ray of lungs excluded lung metastasis and a CT of the abdomen showed that neither the liver nor the lymph nodes around the aortoiliac stems (of the blood ves-

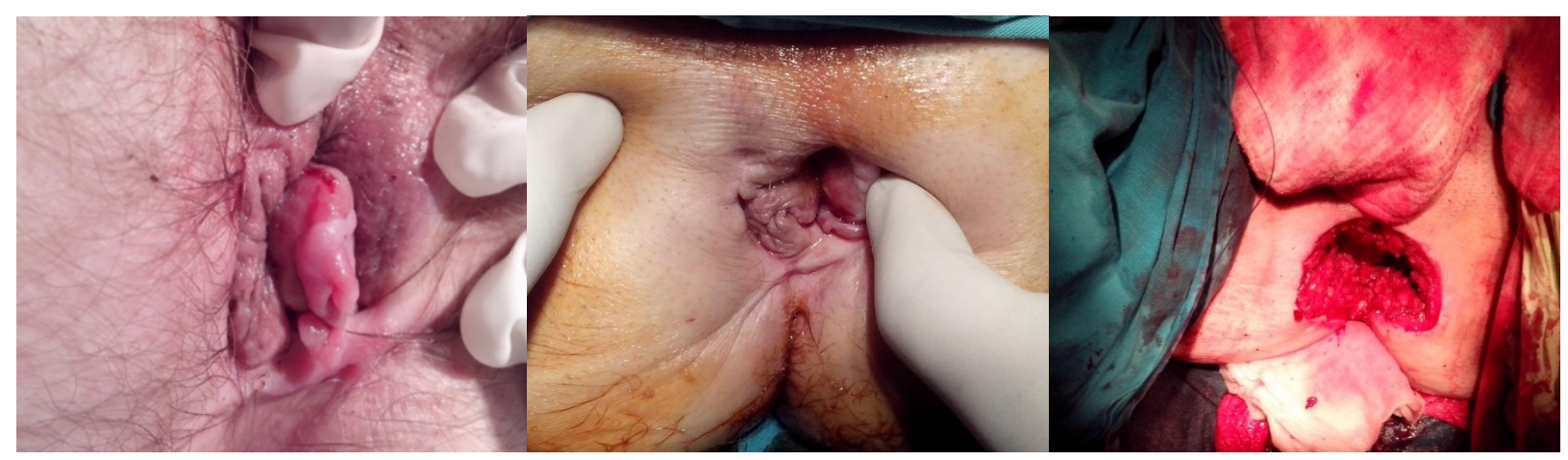

Figure. 1: a Anal SCC carcinoma b Anal SCC stenosisc ELAPE for advanced SCC with incontinence 


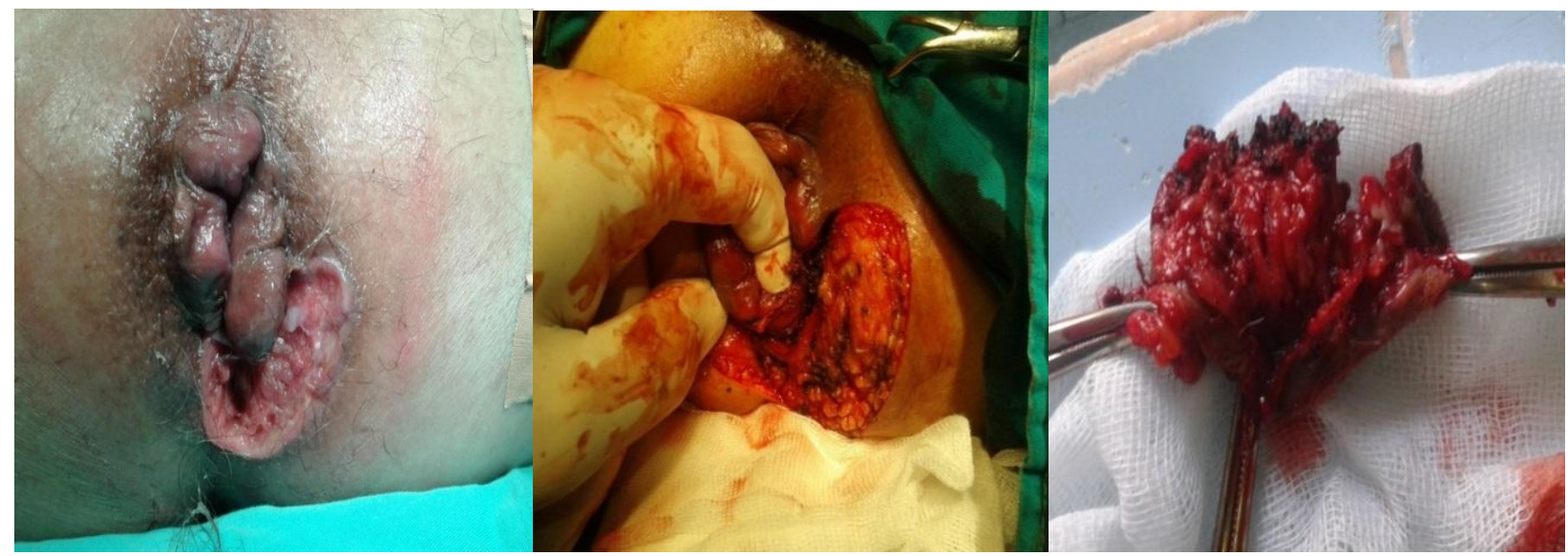

Figure. 2: a Ulcerous marginal SCC b Excision and the anal sphincter exposition c SCC preparation

sels) were affected. He was operated without further delay. The aforementioned dilemma about the type of the treatment was fully present here because of the stenosis at $1 \mathrm{~cm}$ proximally from the anal entrance. After consultations, we decided to remove the possible metastasis source using APR (Figure 1c) as soon as it was possible.

The recovery time needed after performing the anus preternaturalis, a possible period of waiting for CRT, and duration of radiotherapy can be the crucial factors responsible for the possible spreading of the disease into the inguinal lymph nodes or another node or organ. The extraction of perirectal lymph was scheduled in three months' time.

\section{Case report No 3}

The male patient we treated was 65 years old at the time of admission (Figure 2a). He had been previously treated at the Department of internal medicine for three months. The diagnosis was confirmed by excisional biopsy which was, actually, a treatment. The state after the local excision is given in Figure 2b, and the preparation in Figure 2c. Continence was not compromised in this case. Less than six months after the first operation, a small lesion appeared, and both biopsy and a $\mathrm{PH}$ finding confirmed the cancer growth. A deeper and wider reexcision was done without compromising the sphincter function of the anus. Only eight weeks later, another control biopsy determined a relapse. That is why the CRT was applied, without the prophylactic radiation of the inguinal lymph nodes, which were not enlarged when checked both by palpation and CT. Today, three years after the first intervention, the patient feels good. We follow up the patient every six months.

\section{Case report No 4}

A 61-year-old man with a relatively small (T1 T2) but dubious tumorous intra-channel lesion was prescribed the standard CRT. The thin needle biopsy determined intra-anal SCC. Laboratory resultswere

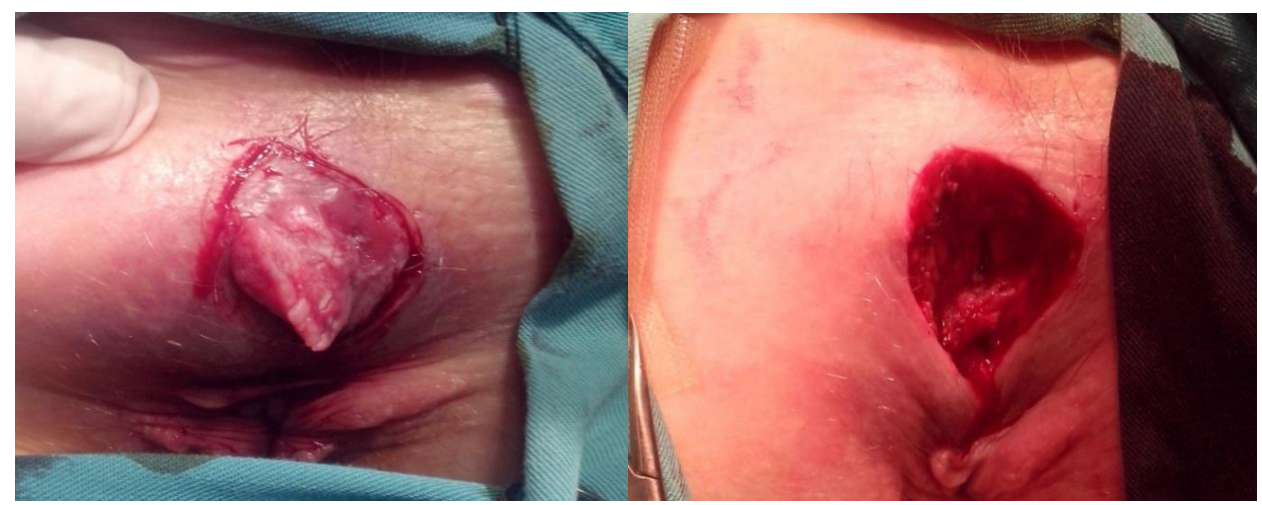

Figure 3: a SCC with a growth into the healthy tissue b A change excided deeply into the healthy tissue 
good. The patient was treated using the conformal radiation method, with the combination of $5 \mathrm{FU}$ and Mitomycin. The disease regressed completely. The clinical check-up included laboratory analyses, both rectal and inguinal palpation, abdominal ultrasound, $X$-rays of the lungs, examinations by a urologist/gynaecologist, taking HPVsmears, and occasional MRIs. The results of all analyses were in range, and we follow up the patient every six months.

\section{Case report No 5}

A female, 56-year-old, had a change in mucosa for the last six months (Figure 3a). The preoperative diagnosis of the perianal carcinoma at the T2 stage was confirmed by a deep excision all the way into the healthy tissue (Figure $3 b$ ). PH findings confirmed the existence of CSS with keratin production. The same finding shows that malignancy occurred on the terrain of an inverted condylomatous papilloma. A year after the intervention, there was no deterioration of the patient's health.

Diagnosis was established by endoscopic and excisional biopsy. Liver and lung metastasis were not diagnosed. The status of lymph nodes in the inguinal region was regular and it was confirmed by inguinal palpation and MSCT. Also, there was no metastatic disease in these five patients at the time of their admission. MRI was done only as a control method. In two patients, the treatment included APR, excision was performed in one patient, and CRT in two cases (in one patient after the second excision). Four of five patients were alive with the follow-up period of one to four years. One patient died six months after intervention due to distant metastasis.

\section{DISCUSSION}

The anal cancer is a rare disease. In the USA 4,200 new patients were registered in 2008 (7), 6,230 in 2011 (8), and about 7,000 in 2013 (9). In Canada, 515 new cases were recorded in 2007, which is the incidence of 1.3 per 100,000 people a year (10). In Serbia (the central part), 21 male and 6 female patients were registered during 2011 (11).

The ratio between gender in the USA was 1:1.8 in 2012 (it affects more women than men) (12). In our series, four men and only one woman were treated. It coincides with the data from the national disease register of Serbia (21:6). In the USA, the number of new cases has doubled over the past 30 years (13). The number of death cases is $12.5 \%$ in relation to the newly discovered cases in 2012 (14).

The literature sources also demonstrate the cases of the rectal (15) and sigmoid (16) SCCs in the so-called transformation i.e. metaplastic zone. The etiopathogenesis of SCC of the rectum is still unclear. Four hypotheses have developed regarding the pathophysiology of the disease: 1 . Some authors point to inflammation or irritation, secondary to inflammatory bowel disease; infection or radiation results in squamous metaplasia from which carcinoma develops; 2. Hicks et al. (17) have described the pluripotent stem cells capable of squamous differentiation. This theory is supported by the fact that squamous carcinoma is often found in the midst of poorly differentiated cells; 3. Michelassi et al. (18) have suggested that epithelial damage causes proliferation of uncommitted basal cells into squa-mous cells which then undergo malignant transfor-mation; 4 . Histological reviews of adeno-carcinomas have demonstrated areas of squamous differentiation, suggesting the possibility that these carcinomas may arise out of pre-existing adenomas or adenocarci-nomas (19). From 1933, seventy-three cases have been reported in the literature written in English (19). Raghavan D. et al. think that is about 100 cases or $0.2 \%$ or less (20).

Squamons cellcarcinoma of this region is often associated with fistulae, hidradenitis suppurativa and inflammatory diseases of the intestines (20). The staging which is generally accepted is based on TNM classification of both Union for International Cancer Control (UICC) and American Joint Committee on Cancer (AJCC).

The main etiological factors are the human papilloma virus (HPV), subtypes 16 and 18, and the HIV virus. Since both the HIV and the more frequent HPV are sexually transmitted diseases, the focus of the research is the population that practises the anal sex, especially homosexuals (21). That is why a suggestion is made to do the screening only of this group(22). HPV is found in $90 \%-95 \%$ of the anal carcinoma patients $(23,24)$. The same virus causes the cancer of the vulva, uterus cervix, vagina and, in men, penis. Any kind of sexual contact can lead to contamination, while condom has no protective role because the virus reservoirs are located at the base of the penis i.e. the perineum (in women) (25). All patients have to be tested for HPV. Since December 2010, the USA has approved Gardasil ${ }^{\circledR}$ and Cervarix ${ }^{\circledR}$, the anti-HPV vaccines with defined indica- 
tions hoping that the initial success will continue (11). The new 9-valent vaccine, which replaced the previous 4-valent one, has the potential to prevent $90 \%$ of the cervical cancers compared to the $70 \%$ of the protection offered by the old vaccine (26). It may also have a preventing effect on the anal carcinoma development. The other known cause of the disease is the HIV virus (4). It is logical that the anal cancer incidence is greater in the homosexual population and those who practise the anal sex. The third large group in which the disease appears is made up of the patients with some kind of an immunodeficient status, including the transplant patients (27). It has been proved that smoking of cigarettes is an independent factor responsible for gene mutations on the level of the anal region and for allowing HPV to persist (26).

That is the reason why every woman with SCC ought to be examined by a gynaecologist and every man should undergo a urological exam (of the penis and prostate), as well as to be tested for the condylomata acuminata disease. The varicose SCC (previously called gigantic condylome or BuschkeLöwenstain tumour) which looks like a big condyloma is also very interesting. Lately the so-called „Lower Anogenital Squamous Terminology“ (LAST) has been used for cervical precancers (8).
Different methods are used in order to discover the disease as early as possible (at the precancerous stage,Table 1): the anal cytology, high-resolution anoscopy (HRA), biopsy of suspiciously-looking changes, and identification of the human papilloma virus (HPV). SCC has been reported to be associated with HPV 16 in up to $93 \%$ of tumors (28).

According to TNM classification, Bowen disease, high-grade squamous intra-epithelial lesion (HSIL) and anal intra-epithelial neoplasms II-III (AIN II-III) fall into this stage (carcinoma in situ).This classification needs to be clarified: there are low-grade squamous intra-epithelial lesions (LSIL), high-grade squamous intra-epithelial lesions (HSIL), and intraepithelial neoplasm can be in the anal (AIN) or perianal region (PAIN) (Table 2) (9).

As for lymph node metastases, sentinel lymph node biopsy (SLNB) of inguinal nodes was proposed in 2000 by John Spratt, who suggested that prophylactic groin dissection is not required but it may be curative in many cases for enlarged nodes or in the presence of a positive SLNB (29). It was proved later that there is a correlationbetween the sizeof lymphnodes and metastasis in them, but the percentage of false negative results is so big that it leads to the conclusion that the very size of the nodes cannotbe anindication for the therapeutic radiation or inguinal lymphade-

Table 1. WHO classification of premalignant lesions

\begin{tabular}{c}
\hline \hline Premalignant lesions \\
\hline Anal intra-epithelial neoplasm (dysplasia), low grade \\
\hline Anal intra-epithelial neoplasm (dysplasia), high grade \\
\hline Bowen's disease \\
\hline Perianal squamous intra-epithelial neoplasm \\
Paget's disease
\end{tabular}

Table 2. Terminology and classification of precancers

\begin{tabular}{cccr}
\hline \hline $\begin{array}{c}\text { LAST } \\
\text { terminology }\end{array}$ & $\begin{array}{c}\text { Bethesda } \\
\text { terminology }\end{array}$ & AIN $^{2}$ terminology & Dysplasia \\
\hline LSIL/AIN1 & LSIL $^{3}$ & $\begin{array}{c}\text { Condylomata acuminata } \\
\text { (anal wart) AIN1 }\end{array}$ & Mild dysplasia \\
\hline HSIL/AIN2-AIN3 & HSIL & AIN 2 & Moderate dysplasia \\
\cline { 2 - 4 } & & AIN 3 & $\begin{array}{r}\text { Severe dysplasia } \\
\text { Carcinoma in situ }\end{array}$ \\
\hline \hline
\end{tabular}

( ${ }^{1}$ LAST - Lower Anogenital Squamous Terminology; ${ }^{2}$ Anal intra-epithelial neoplasm; ${ }^{3}$ Low-grade squamous intra-epithelial lesion; ${ }^{4} \mathrm{HSIL}$ - High-grade squamous intra-epithelial lesion) 
nectomy. In 2013, Tehranian (30) presented a metaanalysis which included 16 studies and 323 patients. According to this analysis, the inguinal detection rate was $86.2 \%(73.4 \%-93.4 \%)$. When both blue dye and radiotracer were used, the detection rate was $90.1 \%$ and the pooled sensitivity was $90 \%$. This is a promising method for discovering cancer in the stage of inguinal lymph node. According to Mis-trangelo et al. (31) the detection rate was $98.4 \%$ and inguinal metastasis were registered in $20.6 \%$ of the patients (13 of 63). It is indicative for all $\mathrm{T}$ stages in order to select patients who are going to be submitted to the inguinal radiotherapy.

Fifty percent of the patients have no distant metastasis at the time of the diagnosis and the fiveyear survival is $80 \%$; $29 \%$ of the patients have regional disease spreading into the lymph nodes and the fiveyear survival is $60 \% ; 12 \%$ of the patients have distant metastases and $30.5 \%$ of them survives the period of five years (32). Depending on the stage, the patients with T1-T2 tumor have $6 \%$ and those with T3-T4 have $16 \%$ of the inguinal metastases. In total, $10 \%$ of the patients have synchronous metastases (33).

\section{TREATMENT}

The treatment of the intra-anal SCCs is primarily a combination of chemo- and radiotherapy. The radiation is performed with approximately $54 \mathrm{~Gy}$ in 28-30 sessions and the chemotherapy includes a combination of mitomycin and 5FU. Lately, cisplatin has been used instead of mitomycin because of high toxicity of mitomycin. The usual dose of the 5FU medicine is $1000 \mathrm{mg} / \mathrm{m}^{2}$, from $1-4$ days ( $1^{\text {st }}$ week) to 29-32 days ( $5^{\text {th }}$ week) with a continuous 24 -hour intravenous infusion. The usual dose of mitomycin is $12 \mathrm{mg} / \mathrm{m}^{2}$. The combination used in recent years includes $60-100 \mathrm{mg} / \mathrm{m}^{2}$ of cisplatin, day 1 with $750-$ $1000 \mathrm{mg} / \mathrm{m}^{2}$ of $5 \mathrm{FU} 24 \mathrm{~h}$ continuous infusion, days $1-4$ or 5. In case of contraindications, cisplatin could be replaced by carboplatin. Another frequently used combination consists of cisplatin $\left(37.5 \mathrm{mg} / \mathrm{m}^{2}\right), 5 \mathrm{FU}$ $\left(500 \mathrm{mg} / \mathrm{m}^{2}\right)$ and ifosfamide $\left(2 \mathrm{~g} / \mathrm{m}^{2}\right)$, days $1-2$ (34). It is proved that a combined treatment gives much better results than the radiation alone. As far as toxicity is concerned, various trials by UKCCCR (United Kingdom Coordinating Committee on Cancer Research), RTOG/ECOG (Radiation Therapy Oncology Group/Eastern Cooperative Oncology Group) and EORTC (European Organization for Research and Treatment of Cancer) demonstrated significant acute dermatologic toxicities in $48 \%-76 \%$ of patients, GI (gastrointestinal) toxicity in $33 \%-45 \%$, and acute hematologic toxicity (HT), grade $3-4$, in up to $61 \%$.

New techniques such as intensity modulated radiotherapy (IMRT) have shown reduced acute toxicity. Brachytherapy (BT) is also an approved method (35). The combination of external beam radiotherapy (EBRT) and BT allows the clinician to deliver higher doses to the tumor and to reduce dose to the normal issue. The most frequently applied BT methods are high-dose-rate (HDR) BT ( $\geq 12 \mathrm{~Gy}$ ), lowdose-rate (LDR) or pulsed dose-rate, PDR (0.5-1 $\mathrm{Gy} / \mathrm{h})$. The anal preservation rate was $61 \%$ and the five-year survival rate was $65 \%$. In more than $90 \%$ of the surviving patients, normal anal function could be preserved (35).Today, brachytherapy is used for small tumours or as the main dose for residual or big tumors after CRT (36).

Small anal cancers, especially SCCs, are treatedwith a local excision extending $1 \mathrm{~cm}$ into the healthy tissue (maximum T1N0 stage), when the disease is either CRT-resistant or recurrent. A reexcision is done in case of recurrence. On the other hand, sur-gical treatment is indicated for advanced tumours in cases of the resistant disease (the disease appears within six months after the CRT) or recurrent disease (after 6 months). Salvage operation is APR or a wide APR (ELAPE) with a 5-year survival rate of $24 \%-47 \%$ (6). Many authors mention better results in the 5-year survival when the operation is done as a primary treatment: from $40 \%$ to $70 \%$ (even between $50 \%-70 \%$ ) with an associated mortality of approximately 3\% (37). With inguinal lymph node involvement, some series showed 5-year survivals of $10 \%$ to $20 \%$ (38). Local failure (LF) rate is about $50 \%$ (39). Because of a growing incidence of the rectal adenocarcinoma, especially the low-localized ones which can grow downward through the anal canal, they are often mixed with anal adenocancers. That is why APR is frequently done in both diseases after the CRT (40). A temporary colostomy is preferred before the definite treatment in cases of the anal canal cancerous stenosis and the anovaginal fistula development, and when acute complications appear or are threatening.

Squamous cell carcinoma usually spreads in a loco-regional manner within and outside the anal canal. Lymph node involvement in diagnosis is observed in $30 \%$ - $40 \%$ of cases, while systemic spread is uncommon with distant extra-pelvic metastasis recorded in $5 \%-8 \%$ at onset, and rates of metastatic progression after primary treatment between $10 \%$ and 
$20 \%$ (25). The inguinal area radiation in the dose of 30 $36 \mathrm{~Gy}$ is applied in case of positive lymph nodes in the inguinal region (13). The sentinel lymph node biopsy (SLNB) can also be applied in case of recurrence after the CRT (13). SLNB can be used within the diagnosis and before any treatment. The complete clinical response to CRT is up to $86 \%$ (37) with survival rates of more than $70 \%$ for the five-year period (9). A tumor response is checked by per-forming a biopsy after minimum of six weeks' time. If a diameter of the tumor is less than $2 \mathrm{~cm}$ and there is no tumor invasion into the anal sphincter, a local excision is recommended, too. The success rate goes up to $90 \%$.

The prophylactic radiation of the inguinal area i.e. of the lymph nodes is questionable. Irradiating the inguinal nodal area in N0 anal canal carcinoma is not necessary. It was proved by the TROG 9902 study which had a goal to find out the rate of isolated inguinal failure in a group of 40 patients with $\mathrm{T} 1$ and $\mathrm{T} 2$ disease. The authors reported $22.5 \%$ inguinal failure with $12.5 \%$ isolated failure as a result of inadequate staging imaging. That is why they left the possibility of treating the inguinal nodes for N0 disease in the absence of adequate imaging $(41,42)$. Regarding stage $\mathrm{T}$, the radiotherapy in all the stages except $\mathrm{T} 1$ is recommended, although there are contradictory opinions (42).

NCCN (National Comprehensive Cancer Network) from USA follows modern treatments of the anal cancer and presents them on its website together with regular updating, the latest version being 1.2016 (43). It contains recommendations for anal and perianal SCCs. According to NCCN, the same therapeutical references are valid for both the anal adenocarcinoma and rectal carcinoma. Beside the abovementioned, the combinations of mitomy-cin/5FU or mitomycin/capecitabine are also recommended as the first line of chemotherapy, and for the metastatic disease - the chemotherapy based on cisplatin. For small tumors of the perianal area, the presented re- commendation is the already mentioned local excision followed by a re-excision in cases of recurrence. Follow-up examinations are advised every 2 or 3 months i.e. more frequently than usual. The appearance of the disease in the inguinal lymph nodes includes the inguinal dissection (43).

The perianal cancers have a slightly better prognosis and the primary choice is a wide excision. The recommended resection margin is $1 \mathrm{~cm}$ (44). There are different opinions about the tumor size which is considered to be adequate for a local excision: some say it is $2 \mathrm{~cm}$ in diameter (T1), while others consider $7 \mathrm{~mm}$ in diameter with the excision into the healthy tissue of $3 \mathrm{~mm}$. In case of a recurrence $-18 \%-63 \%$ (45) or a positive margin, both a re-excision and an additional CRT are recommended (5).

A residual or recurrent disease in the pelvis is treated operatively (after restaging). A metastatic disease outside the pelvis is most frequently found in the liver, lungs and extra-pelvic lymph nodes. About $10 \%-20 \%$ of the patients with an anal carcinoma develop extra-pelvic MS. The appropriate treatment is CRT, and surgical intervention is recommended for certain metastatic locations, including an inguinal nodal dissection (5).

\section{CONCLUSION}

Our series of five patients shows all the varieties of anal cancers and the exigency for a multimodal approach. The SCC should always be suspected when persistent anal symptoms or persistent lesions (especially the ulcerous ones) are present. The morphological types of the anal carcinoma, either the ulcerous or the tumor (a protrusion), are classified as SCC. Neither belonging to one of the risky sexual groups nor the viral etiology of the disease was confirmed in any of our patients. Incontinence in anal carcinoma represents an indication for APR. 


\section{References}

1. Pernot $\mathrm{S}$, Terme $\mathrm{M}$, Zaanan $\mathrm{A}$, et al. Immunity and squamous cell carcinoma of the anus: Epidemiological, clinical and therapeutic aspects. Clin Res Hepatol Gastroenterol 2014;38:18-23. http://dx.doi.org/10.1016/j.clinre.2013.07.002

2. NCCN guadlines 2.2013: Anal carcinoma; www.NCCN.org

3. Fuchshuber PR, Rodriguez-Bigas M, Weber T, Petrelli NJ. Anal Canal and Perianal Epidermoid Cancers. J Am Coll Surg 1997;185:494-505. http://dx.doi.org/10.1016/S1072-7515(01)00967-X

4. Martellucci J, Naldini G, Colosimo C, et al. Accuracy of endoanal ultrasound in the followup assessment for squamous cell carcinoma of the anal canal treated with radiochemotherapy. Surg Endosc 2009;23:1054-7. http://dx.doi.org/10.1007/s00464-008-0130-7

5. de Winton E, Heriot AG, Ng M, et al. The impact of 18-fluorodeoxyglucose positron emission tomography on the staging, management and outcome of anal cancer. British Journal of Cancer 2009;100:693-700.

doi:10.1038/sj.bjc.6604897

6. Nigro ND, Vaitkevicius VK, Considine B. Combined therapy for cancer of the anal canal: A preliminary report. Dis Col \& Rect 1973;17:354-6. http://dx.doi.org/10.1007/BF02586980

7. Welton ML, Varma MG. Anal cancer. In: Beck ED. Et al. (ed). The ASCRS Manual of Colon and Rectal Surgery. Springer science. New York 2009:651.

8. Expert Panel on Radiation Oncology-Rectal/Anal Cancer et al. ACR Appropriateness Criteria ${ }^{\circledR}-$ Anal Cancer 2014;7:4-14.
9. Osborne MC, Maykel J, Johnson EK, Steele SR. Anal squamous cell carcinoma: An evolution in disease and management. World J Gastroenterol 2014;20(36):13052-9.

http://dx.doi.org/10.3748/wjg.v20.i36.13052

10. Spithoff K, Cummings B, Jonker D, Biagi JJ. Clinical Oncology 2014;226:473-87.

http://dx.doi.org/10.1016/j.clon.2014.03.005

(Statistics Canada. Cancer incidence in Canada 2004 to 2005. Ottawa (ON): Statistics Canada 2007).

11. Institut za javno zdravlje Srbije. Incidencija i mortalitet u Centralnoj Srbiji 2011. (tabela 23). Beograd 2013.(serb.)

12. Johnson LG, Madeleine MM, Newcomer LM, et al. Anal cancer incidence and survival: the surveillance, epidemiology, and end results experience, 1973-2000. Cancer 2004;101(2):281. http://dx.doi.org/10.1002/cncr.20364

13. Martin FT, Kavanagh D, Waldron R. Squamous Cell Carcinoma Of The Anal Canal. Surgeon 2009;4:232-7.

http://dx.doi.org/10.1016/S1479-666X(09)80091-7

14. Glover P, Tang SJ, Bhaijee F, Lah CJ. Anal Carcinoma. Video Journal and Encyclopedia of GI Endoscopy 2013;1(2):296-8. http://dx.doi.org/10.1016/S2212-0971(13)70128-6

15. Dyson T, Draganov PV. Squamous cell cancer of the rectum. World J Gastroenterol 2009;15:4380-6. http://dx.doi.org/10.3748/wjg.15.4380

16. Hashimoto N, Kobayashi J, Hara M, et al. Primary Squamous Cell Carcinoma of the Sigmoid Colon. Jpn J Gastroenterol Surg 2013;46(4):302-9. http://doi.org/10.5833/ijgs.2012.0158 
17. Kassir R,Baccot S,Bouarioua N,et al. Sqamous cell carcinoma of middle rectum: Literature review. Int J Surg Case Rep. 2014;5(2):86-90. https://www.ncbi.nlm.nih.gov/pmc/articles/PM C3921652/doi:10.1016/j.ijscr.2013.12.011

18. Scaringi S, Bisogni D, Messerini L, Bechi P. Squamous cell carcinoma of the middle rectum: Report of a case and literature overview. International Journal of Surgery Case Reports 7 (2015) 127-129.

DOI:http://dx.doi.org/10.1016/j.ijscr.2014.10.097

19. Slesser AA, Bhangu A, Bowera M, et al. PP. A systematic review of anal squamous cell carcinoma in inflammatory bowel disease. Surg Oncol 2013;22:230-7.

http://dx.doi.org/10.1016/j.suronc.2013.08.002

20. Raghavan D, Brecher ML, Johnson DH, et al. Textbook of Uncommon Cancer; Small cell carcinomas of gastrointestinal tract: 433 .

21. Joseph DJ, Miller JW, Wu X, et al. Understanding the Burden of Human Papillomavirusassociated Anal Cancers in the US. Cancer 2008;113(10 Suppl): 2892-900.

doi:10.1002/cncr.23744

22. Liszewski W, Rogers N. Response to: "Anal cancer screening" J Am Acad Dermatol 2015;72(2):368.

http://dx.doi.org/10.1016/j.jaad.2014.10.041

23. Steinau M, Unger ER, Hernandez BY, et al. Human papillomavirus prevalence in invasive anal cancers in the United States before vaccine introduction. J Low Genit Tract Dis. 2013;17(4):397-403.

http://dx.doi.org/10.1097/LGT.0b013e31827ed372

24. The HPV And Anal Cancer Foundation. Anal cancer. Available on:

http://www.analcancerfoundation.org/learn/anal -cancer/

25. Gervaz P, Allal, Villiger P, et al. Squamous cell carcinoma of the anus: another sexually transmitted disease. Swiss Med Wkly 2003;133:353-9.
26. Slomski A. New HPV Vaccina Provides Wider Protection. JAMA 2015;313(16):1609. Avalable on: jama.jamanetwork.com. doi:10-1001/jama.2015.3851.

27. Aggarwal A, Duke S, Glynne-Jones R. Anal Cancer: Are We Making Progress? Curr Oncol Rep 2013;15:170-1.

http://dx.doi.org/10.1007/s11912-013-0296-6

28. Blumetti J, Bastawrous AL. Epidermoid cancers of the anal canal: current treatment. Clin Colon Rectal Surg 2009;22:77-83.

http://dx.doi.org/10.1055/s-0029-1223838

29. Spratt JS. Cancer of the anus. J Surg Oncol 2000;74:173-4.

30. Tehranian S, Treglia G, Krag DN, Kakhki VRD, Zakavi SR, Sadeghi R, Keshtgar M. Sentinel Node Mapping in Anal Canal Cancer: Systematic Review and Meta-Analysis. Gastro-intestin Liver Dis 2013;22(3):321-8.

31. Mistrangelo DM, Bello M, Cassoni $\mathrm{P}$, et al. Value of staging squamous cell carcinoma of the anal margin and canal using the sentinel lymph node procedure: an update of the series and a review of the literature. British $\mathrm{J}$ Cancer 2013;108:527-32.

http://dx.doi.org/10.1038/bjc.2012.600

32. Altekruse SF, Kosary CL, Krapcho M. et al. SEER Cancer Review, 1975-2007. 2010. Available on: http://seer.cancer.gov/

33. Gerard JP, Chapet O, Samiei F, et al. Management of inguinal lymph node metastases in patients with carcinoma of the anal canal: experience in a series of 270 patients treated in Lyon and review of the literature. Cancer 2001;92(1):77-84. DOI: 10.1002/1097-0142(20010701)92:13.0.CO;2-P

34. Leon O, Guren M, Hagberg O, et al. (Nordic guidelines group). Anal carcinoma - Survival and recurrence in a large cohort of patients treated according to Nordic guidelines. Radiotherapy and Oncology 2014;113:352-8.

http://dx.doi.org/10.1016/j.radonc.2014.10.002 
35. Niehoff P, Kovács G. HDR brachytherapy for anal cancer. J Gastrointest Oncol 2014;5(3):218-22. http://dx.doi.org/10.3978/j.issn.2078-6891.2014.027

36. Khosla D, Kumar R, Kapoor R, Sharma SC. Sphincter Preservation in Anal Cancer: A Brief Review. Saudi J Gastroenterol. 2013;19(3):101-7. http://dx.doi.org/10.4103/1319-3767.111949

37. Poggio JP. Premalignant Lesions of the Anal Canal and Squamous Cell Carcinoma of the Anal Canal. Clinics In Colon And Rectal Surgery 2011;24:177-92.

http://dx.doi.org/10.1055/s-0031-1286002

38. Stephen Ko. Anal Cancer. In: Abraham J, Gulley JL, Allegra CJ. The Bethesda Handbook Of Clinical Oncology, fourth edition. Lippincott Williams \& Wilkins, a Wolters Kluwer business, Philadelphia 2014:180-93.

39. Scher ED, Ahmed I, Yue NY, Jabbour SK. Technical aspects of radiation therapy for anal cancer. J Gastrointest Oncol 2014;5(3):198-211. http://dx.doi.org/10.3978/j.issn.2078-6891.2014.026

40. Eng C. Carcinoma of the Anal Canal: Small Steps in Treatment Advances. Clin Adv Hematol Oncol 2011;9(9):662-9.
41. Mallick M, Benson R, Julka PK, Rath GK. Shifting Paradigm in the Management of Anal Canal Carcinoma. J Gastrointest Canc 2015;46:14. http://dx.doi.org/10.1007/s12029-014-9673-0

42. Matthews JHL, Burneister BH, Borg M, et al. T12 anal carcinoma requires elective inguinal radiation therapy - The results of Trans Tasman Radiation Obcology Group study TROG 99.02. Radiotherapy and Oncology 2011;98:93-8. http://dx.doi.org/10.1016/j.radonc.2010.10.005

43. NCCN. NCCN Clinical Guidelines in Oncology (NCCN Guidelines ${ }^{\circledR}$ ) ANAL CARCINOMA, Versiion 1.2016. Available on: www.mccm.org http://www.nccn.org/professionals/physician gl s/pdf/anal.pdf

44. Fleshner PR, Chalasani S, Chang GJ, et al. Practice parameters for anal squamous neoplasms. Dis Colon Rectum. 2008;51(1):2-9.

45. Wietfeldt ED, Thiele J. Malignancies of the Anal Margin and Perianal Skin. Clin Colon Rectal Surg 2009;22:127-35. http://dx.doi.org/10.1055/s-0029-1223845 


\title{
Analni karcinom: prikaz mini-serije bolesnika i pregled literature
}

\author{
Momčilo Stošić ${ }^{1}$, Igor Stojanović ${ }^{1}$, Svetlana Mihajlović ${ }^{1}$, Kosta Zdravković ${ }^{2}$ \\ ${ }^{1}$ Odeljenje za hirurgiju, Zdravstveni centar Vranje, Vranje, Srbija \\ ${ }^{2}$ Dnevna bolnica za hemoterapiju, Zdravstveni centar Vranje, Vranje, Srbija
}

\section{SAŽETAK}

Povod za pisanje rada je prikaz naših bolesnika. Cilj rada bio je da se skrene pažnja na analni karcinom i njegove različite histološke potkategorije i da se prikažu standardni i novi stavovi iz literature. U radu je prikazana naša serija slučajeva i mesto hirurškog tretmana, posebno kod inkontinentnih bolesnika. Analni karcinom je retko oboljenje koje čine više patohistoloških (PH) različitih tipova karcinoma, oko 2,5\% svih digestivnih karcinoma. Tretman oboljenja je multimodalitetni. Još uvek ima nepoznanica u etiologiji, klasifikaciji, dijagnostici ovog oboljenja. Postoje dileme oko skrininga prekanceroznih lezija i tretmana dijagnostikovane inkontinencije. Složena anatomija $\mathrm{i}$ histologija analne regije je razlog nedoumica. Koincidencija sa virusnom infekcijom i razvojem prekanceroza je visoka.

U poslednje tri godine (2013 - 2015) u regionalnoj bolnici, koja zdravstveno obezbeđuje oko 300.000 stanovnika, dijagnostikovano je i lečeno pet slučajeva analnog karcinoma. Ovome je pridodat jedan slučaj od ranije, ukupno šest prikazanih u retrospektivnom radu. Primenjeno lečenje je upoređeno sa stavovima iz literature.

Bolest je u pet slučajeva patohistološki potvrđena kao analni i perianalni skvamozno-celularni kancer (SCC, squamous-cellular carcinoma), a kod jednog bolesnika analni adenokarcinom (AAC). Troje bolesnika je bilo inkontinentno na prijemu i amputacija rektuma je jedno od primenjenih rešenja. Preporuke iz literature nisu jasno određene za ove bolesnike. Opredelili smo se za amputaciju rektuma. Pregledom literature prikazujemo sve moguće opcije.

Razlika u histološkoj strukturi dovodi do konfuzije u lečenju. Polovina od ukupnog broja naših bolesnika bila je inkontinentna na prijemu, te ističemo dilemu tretmana ovih bolesnika za koje liteteraturne preporuke nisu decidirane. Potreban je individualan pristup. Mi smo radili amputaciju rektuma pre nego li standardizovano hemio-radioterapijsko lečenje. Osvrtom na literaturu prikazujemo sve moguće opcije.

Ključne reči: analni karcinom, skvamozno-ćelijski, hemio-radioterapija 
Professional article 